\title{
ANALISIS KESALAHAN STRUKTUR FRASA DALAM TEKS EKSPOSISI SISWA KELAS X SMA NEGERI 15 MEDAN TAHUN PEMBELAJARAN 2016/2017
}

\author{
Oleh \\ Novita S B Berutu (novita.berutu.@yahoo.co.id) \\ Drs. Sanggup Barus, M.Pd.
}

\begin{abstract}
ABSTRAK
Penelitian ini bertujuan untuk mendeskripsikan bentuk kesalahan struktur frasa dalam teks eksposisi siswa kelas X SMA Negeri 15 Medan Tahun Pembelajaran 2016/2017. Sumber data penelitian ini adalah teks eksposisi siswa kelas X SMA Negeri 15 Medan tahun pembelajaran 2016/2017. Data dalam penelitian ini adalah kesalahan struktur frasa siswa kelas X SMA Negeri 15 Medan tahun pembelajaran 2016/2017. Metode penelitian yang digunakan adalah metode deskriptif kualitatif, yaitu mendeskripsikan suatu keadaan alamiah mengenai kesalahan struktur frasa dalam teks eksposisi siswa kelas X SMA Negeri 15 Medan.Untuk menemukan dan mengklasifikasikan kalimat yang mengandung unsur kesalahan struktur frasa digunakan teknik membaca dan mencatat.Instrumen dalam penelitian ini adalah peneliti sendiri (Human Instrument).Hasil penelitian menunjukkan bahwa pada menulis teks eksposisi sisa kelas X SMA Negeri 15 Medan ditemukan kesalahan struktur frasa. Bentuk kesaalahan struktur frasa teks eksposisi siswa kelas X SMA Negeri 15 Medan tahun Pembelajaran 2016/2017 terbagi atas lima macam, yaitu frasa benda, frasa kerja, frasa sifat, frasa depan dan frasa keterangan. Dari kelima bentuk kesalahan struktur frasa tersebut terdapat bentuk kesalahan yang paling menonjol, yaitu frasa depan.
\end{abstract}

Kata kunci: Kesalahan Berbahasa, Frasa dan Teks Eksposisi

\section{PENDAHULUAN}

Peningkatan mutu pendidikan merupakan salah satu program pemerintah untuk mencerdaskan kehidupan bangsa mulai dari tingkat sekolah dasar sampai perguruan tinggi.Dunia pendidikan memiliki peranan penting dalam peningkatan sumber daya alam manusia dan dalam menjamin pertumbuhan, perkembangan serta kelangsungan hidup suatu bangsa.Oleh karena itu, bidang pendidikan perlu mendapatkan perhatian, penanganan dan prioritas secara intensif baik oleh pemerintah, masyarakat, maupun pengelola pendidikan.

Peningkatan mutu pendidikan tidak terlepas dari proses pembelajaran bahasa. Bahasa merupakan alat komunikasi yang digunakan manusia untuk berinteraksi dalam kehidupannya.Untuk dapat berkomunikasi dengan baik, seseorang perlu berbahasa yang baik dan benar. 
Pengajaran bahasa dapat bersifat informal dan bersifat formal.Pengajaran bahasa yang bersifat informal biasanya terjadi di lingkungan keluarga, dalampergaulan dengan tetangga dekat, teman sepermainan, atau dalam pergaulan antaretnik.Pengajaran bahasa yang bersifat formal terjadi di sekolah.Pengajaranbahasa yang bersifat informal biasanya disebut dengan pengajaran bahasa secaraalamiah sedang pengajaran bahasa secara formal disebut dengan istilah pengajaranbahasa secara ilmiah.Pengajaran bahasa secara formal yang dilakukan di sekolah diarahkanuntuk meningkatkan potensi peserta didik dalam berkomunikasi, baik secara lisanmaupun tertulis.

Oleh karena itu, pembelajaran bahasa Indonesia selalu disertakan dalam kurikulum jenjang pendidikan di sekolah. Dalam berbahasa terdapat beberapa keterampilan yang saling berhubungan.Menurut Tarigan (2005: 1) "Keterampilan berbahasa mempunyai empat komponen, yaitu; keterampilan menyimak, keterampilan berbicara, keterampilan membaca dan keterampilan menulis".Dalam hal ini, menulis dianggap keterampilan yangpaling sulit tingkatannya.Ada banyak faktor yang mempengaruhinya, baik daridiri seseorang itu sendiri ataupun faktor lingkungan. Ada yang beranggapan,menulis merupakan bakat dan skill yang dimiliki seseorang sejak lahir. Pendapatitu barangkali ada benarnya, akan tetapi bakat saja tentu tidak cukup. Menulissesungguhnya dapat dipelajari dan diajarkan, butuh ketelitian, ketekunan,kesabaran, dan kemauan untuk dapat menjadi seorang penulis.

Salah satu keterampilan berbahasa yang paling penting adalah keterampilan menulis, tidak hanya dalam kehidupan berpendidikan akan tetapi sangat penting dalam kehidupan bermasyarakat. Melalui kegiatan menulis siswa dapat mengungkapkan dan mengekspresikan gagasan atau pendapat, pemikiran, dan perasaan yang dimiliki, selain itu menulis juga dapat mengembangkan daya pikir dan kreativitas seorang siswa. Menurut Tarigan (2008:4) "Keterampilan menulis sangat dibutuhkan di era kehidupan modern karena ketrampilan menulis merupakan suatu ciri dari orang yang terpelajar atau bangsa yang terpelajar". Namun pada kenyataannya, keterampilan menulis tersebut tidak sejalan dengan kemampuan dan minat siswa dalam pembelajaran menulis.

Salah satu kompetensi dasar 4.4 dalam silabus mata pelajaran bahasa Indonesia kelas $\mathrm{X}$ yang harus dikuasai oleh siswa yaitu mampu mengonstruksikan teks eksposisi dengan memerhatikan isi (permasalahan, argumen, pengetahuan, dan rekomendasi), struktur dan kebahasaan.Namun, harapan tersebut tidak sinkron dengan hasil yang ditunjukkan di lapangan. Masih banyak siswa yang melakukan kesalahan ketika menulis teks. Salah satu kesalahan yang dilakukan adalah kesalahan penulisan frasa dalam teks yang dibuat oleh siswa.Frasa merupakan bagian penting dalam peningkatan kemampuan berbahasa, karena 
frasa sebagai salah satu satuan sintaksis yang memberikan dasar pemahaman seluk beluk kalimat.Hanya saja menurut pengalaman penulis pembelajaran frasa di sekolah belum mendapatkan porsi yang cukup.Beberapa siswa masih belum mengetahui pengertian frasa dan jenis-jenis frasa.Buku teks pegangan siswa masih memuat materi tentang frasa yang sangat terbatas dan bersifat umum.Hal tersebut menyebabkan teks yang dibuat oleh siswa menjadi tidak koheren.

Menulis sebuah teks yang baik dan benar memerlukan penguasaan beberapa keterampilan.Tetapi dalam pembelajaran bahasa Indonesia, materi yang dirasa sulit oleh para siswa justru menulis terutama menulis sebuah teks.Apabila siswa tidak memenuhi aturanaturan kebahasaan tertulis terjadilah kesalahan berbahasa.Salah satu kesalahan berbahasa yang masih sering dilakukan siswa adalah kesalahan sintaksis, khususnya kesalahan dalam bidang frasa. Menurut penelitian Istinganah (2012) dengan judul "Analisis Kesalahan Sintaksis pada Karangan Narasi Ekspositoris Siswa Kelas VII SMP Negeri 1 Banguntapan Bantul Yogyakarta" yang menyatakan bahwa kesalahan penggunaan struktur frasa dalam karangan narasi ekspositori siswa Kelas VII SMP Negeri 1 Bangunapan Bantul Yogyakarta meliputi enam kesalahan, yaitu penggunaan preposisi yang tidak tepat, susunan kata yang tidak tepat, penggunaan unsur yang berlebihan atau mubazir, penggunaan bentuk superlatif yang berlebihan, penjamakan yang ganda dan penggunaan bentuk resipokal yang tidak tepat. Kesalahan berbahasa dalam keterampilan menulis tersebut terjadi akibat kekurangpahaman siswa terhadap kaidah tata bahasa pada bidang sintaksis.Kekurangpahaman siswa terhadap kaidah tata bahasa dalam bidang frasa ketika menulis sebuah karangan tampak dalam penggunaan kalimat dalam karangan.

Penelitian Hadiyati Wulan Dani yang berjudul "Penggunaaan Frasa dalam Karangan Narasi pada Siswa Kelas X SMA Negeri 4 Tangerang Selatan" menyatakan bahwa frasa endosentris lebih banyak digunakan oleh siswa daripada frasa eksosentris.Hal tersebut disebabkan oleh kurangnya pengetahuan siswa mengenai frasa secara eksplisit. Selain itu penelitian yang sama juga dilakukan oleh Amalia (2013) yang melakukan penelitian dalam skripsinya yang berjudul "Kesalahan Berbahasa Tataran Frasa dalam Karangan Siswa Kelas VIII SMP Negeri 30 Semarang" menyatakan kurang mampunyai siswa dalam menulis karangan yang baik dan benar dan ketidaktahuan siswa akan kesalahan berbahasa yang telah dilakukannya. Kedua hal tersebut merupakan salah satu faktor penyebab kesalahan frasa dalam karangan yang dibuat siswa.

Abdul Raxak Arsyad (2001) dengan penelitianya "Analisis Penggunaan Frasa dalam Kalimat pada Karangan Siswa Kelas III SLTP Negeri 27 Jakarta Timur”. Hasil penelitian ini 
menunjukkan bahwa dari 70 karangan terdapat 2061 penggunaan frasa, berdasarkan distribusi dalam kalimat terdapat frasa endosentrik sebanyak $1922(93,26 \%)$ dan frasa eksosentrik sebanyak $139(6,78 \%)$. Hal ini berarti frasa eksosentrik lebih banyak digunakan oleh siswa untuk mengungkapkan ide atau gagasannya.Hal tersebut disebabkan kurangnya pengetahuan siswa mengenai frasa secara eksplisit.

Wening Wulan (2013) dengan penelitiannya "Analisis Kesalahan Kontruksi Sintaksis pada Karangan Argumentasi Siswa Kelas XI SMK YPKK 2 Sleman”. Hasil Penelitian ini menunjukkan bahwa kesalahan struktur frasa karena susunan kata yang tidak tepat sebanyak $0,82 \%$ dan ketidaktepatan unsur frasa sebanyak 0,14 \%. Hla tersbut disebabkan kurangnya kemapuan siswa dalam menulis dan kurangnya gramatikal siswa tersebut.

Dari penelitian-penelitian tersebut jelas bahwa masih banyak siswa melakukan kesalahan berbahasa khususnya kesalahan struktur frasa ketika menulis sebuah teks eksposisi.Hal senada juga diungkapkan salah satu guru SMA Negeri 15 Medan melalui wawancara diperoleh informasi kurangnya kemampuan menulis teks eksposisi dengan baik dan benar. Hal itu dikemukakan oleh guru bahasa Indonesia yaitu Risda Simarmata di SMA Negeri 15 Medan. Berdasarkan wawancara pada bulan September 2016 dengan Ibu Risda Simarmata diperoleh informasi ternyata hampir seluruh siswa, khususnya kelas X, kurang mampu dalam kegiatan menulis, termasuk menulis teks eksposisi yang koheren.

Sesuai dengan keterangan yang diperoleh dari guru pengampu mata pelajaran bahasa Indonesia yang menyatakan bahwa kesalahan yang dilakukan siswa saat menulis teks eksposisi terjadi akibat siswa kurang berminat menulis sebuah teks, siswa kurang paham mengenai kaidah tata bahasa Indonesia dan adanya kecerobohan yang dilakukan oleh siswa tersebut. Hal ini dapat dibuktikan dengan persentase pencapaian nilai menulis teks eksposisi hanya mencapai $40 \%$ saja.Hasil ini dapat dilihat dari hasil belajar siswa yang belum mencapai Kriteria Ketuntasan Minimum (KKM) yang ditetapkan di SMA Negeri 15 Medan yaitu sebesar 75.Rata-rata ketuntasan nilai yang diperoleh siswa hanya $40 \%$.

Berdasarkan latar belakang tersebut, penelitian ini berkaitan dengan kesalahan berbahasa, khususnya kesalahan struktur frasa.Hal ini menarik untuk dibahas karena peneliti merasa bahwa sebagian besar tulisan siswa menyimpang dari kaidah penulisan yang benar. Peneliti memilih frasa sebagai bahan penelitian karena mengingat begitu pentingnya penggunaan frasa dalam pembelajaran bahasa Indonesia di sekolah untuk mendukung gagasan atau ide yang akan diungkapkan oleh penulis dalam menulis sebuah teks. Hal tersebut juga didasarkan pada fenomena di lapangan dan juga banyak hasil penelitian yang 
menunjukkan adanya kesalahan frasa yang dilakukan oleh siswa ketika menulis teks eksposisi.

Kesalahan frasa sering dilakukan dalam bahasa lisan maupun tulis, akan tetapi dianggap benar karena sudah menjadi kebiasaan. Oleh karena itu, peneliti tertarik untuk mengetahui dan mempelajari lebih dalam kesalahan berbahasa tataran frasa pada teks yang dibuat oleh siswa.Adapun judul penelitian yang dibuat adalah "Analisis Kesalahan Struktur Frasa dalam Teks Eksposisi Siswa Kelas X SMA Negeri 15 Medan Tahun Pembelajaran 2016/2017."

\section{METODE PENELITIAN}

Metode penelitian adalah suatu cara dalam proses pemecahan masalah dengan mengumpulkan dan menganalisis data untuk mencapai tujuan yang digunakan. Tujuan yang dimaksud adalah untuk menguji serangkaian pertanyaan penelitian dengan pengetahuan atau cara yang dipakai dalam penelitian, maka dengan sendirinya mudah untuk memperoleh data yang dibutuhkan.Pemilihan suatu metode tertentu harus disesuaikan dengan tujuan penelitian.Oleh karena itu, metode yang digunakan dalam penelitian ini adalah metode deskriptif kualitatif.Moleong (2006:8) mengatakan, "Salah satu karakteristik penelitian kualitatif adalah deskriptif."

Penelitian deskriptif ini digunakan untuk menjelaskan data yang sudah terkumpul oleh penulis dan juga dengan menggunakan metode ini dapat mendeskripsikan kesalahan struktur frasa dalam teks eksposisi siswa kelas X SMA Negeri 15 Medan.

\section{HASIL PENELITIAN DAN PEMBAHASAN}

\section{Hasil Penelitian}

Hasil penelitian ini berupa deskripsi kesalahan struktur frasa dalam teks eksposisi siswa kelas X SMA Negeri 15 Medan Tahun Pembelajaran 2016/2017. Seperti yang telah dibicarakan terdahulu data dalam penelitian ini berupa kesalahan struktur frasa siswa kelas $\mathrm{X}$ SMA Negeri 15 Medan Tahun Pembelajaran 2016/2017 dan sumber data adalah teks eksposisi siswa kelas X SMA Negeri 15 Medan tahun pembelajaran 2016/2017.

Kesalahan struktur frasa dalam teks eksposisi yang dibuat oleh siswa terdiri dari kesalahan struktur frasa benda, frasa kerja, frasa sifat dan frasa depan serta frasa keterangan. Hal tersebut diperoleh berdasarkan penyeleksian data yang telah dilakukan sebagai bagian dari proses analisis dengan membaca cermat dan berulang-ulang. Penelitian ini akan dinalisis secara deskriptif kualitatif. 
Berdasarkan penelitian yang dilakukan peneliti pada karangan siswa kelas X SMA Negeri 15 Medan tahun pembelajaran 2016/2017, ditemukan berbagai kesalahan struktur frasa.Peneliti mengutip teks siswa yang mengalami kesalahan struktur frasa kemudian diberikan penjelasan/pendeskripsian dengan kaidah yang berlaku lalu diberikan pembenaran terhadap struktur frasa yang salah tersebut. Mengingat cukup banyaknya temuan kesalahan struktur frasa pada teks siwsa dalam penelitian ini, maka tidak semua kesalahan yang ditemukan akan dijelaskan disini. Peneliti hanya akan menjelaskan beberapa bentuk kesalahan struktur frasa yang sering terjadi dala teks siswa untuk dijadikan sebagai contoh.

\section{Pembahasan}

Berdasarkan hasil penelitian, dapat diketahui bahwa terdapat kesalahan struktur frasa dalam teks ekposisi siswa kelas X SMA Negeri 15 Medan Tahun Pembelajaran 2016/2017.Hal tersebut terjadi karena siswa belum mampu menulis sesuai dengan kaidah tata bahasa Indonesia. Tabel data kesalahan struktur frasa menunjukkan bahwa siswa masih belum memahami penulisan struktur frasa yang baik dan benar. Hal tersebut terlihat dari bentuk kesalahan struktur frasa yang dibuat oleh siswa yaitu kesalahan struktur frasa benda, frasa kerja, frasa sifat, frasa depan dan frasa keterangan.

Dari kelima bentuk kesalahan struktur frasa dalam teks eksposisi siswa tersebut terlihat bahwa kesalahan struktur frasa depan adalah kesalahan struktur yang paling sering dilakukan oleh siswa kelas X SMA Negeri 15 Medan Tahun Pembelajaran 2016/2017. Dan juga banyaknya kesalahan struktur frasa yang dibuat oleh siswa tidaklah sama. Ada kesalahan struktur frasa yang ditemukan hanya satu, dua bahkan lebih dari bentuk kesalahan struktur frasa, ada pula yang tidak ada sama sekali. Hal ini menunjukkan bahwa sistematika penulisan dan pemahaman siswa mengenai struktur frasa harus lebih ditingkatkan lagi.Berdasarkan analisis data yang telah dijelaskan pada bagian sebelumnya, dapat diketahui bahwa dalam memproduksi teks eksposisi, siswamenghasilkan teks eksposisi yang berbeda-beda bentuknya dancara penyampaian. Demikian juga dengan jenis struktur frasa yang digunakan, setiap teks yang diproduksi siswa mempunyai jenis struktur frasa yang berbeda-beda.

Berdasarkan analisis yang telah dilakukan, dapat diketahui bahwa dalam menulis teks eksposisi siswa cenderung memiliki kesalahan dibidang frasa, yaitu struktur frasa.

Kesalahan tersebut sering terjadi karena pada kenyataannya siswa hanya meniru contohcontoh teks yang ada tanpa memahami sistematika penulisan yang sesuai dengan kaidah tata bahasa Indonesia.Banyak siswa tidak melihat bagaimana sistematika penulisan teks eksposisi yang benar dan menggunakan cirri kebahasaan yang baik dan benar.Hal tersebut 
menyebabkan pemahaman akan sistematika penulisan teks yang baik dan benar masih rendah.

Banyak siswa yang belum mengetahui kaidah penulisan struktur frasa yang baik dan benar. Siswa hanya mengandalkan pengetahuan yang saat itu dimilikinya tanpa mencari tahu atau membaca pedoman penulisan yang baku. Selama melakukan observasi terhadap siswa kelas X SMA Negeri 15 Medan, peneliti menemukan bahwa ketika siswa dihadapkan pada proses pembelajaran, siswa kurang memperhatikan atau merespon pembelajaran yang telah disampaikan. Hal ini mungkin disebabkan oleh kurangnya waktu pemeblajaran yang teah ditetapkan, padahal untuk melakukan proses pembelajaran yang baik diperlukan waktu yang lumayan banyak agar siswa mampu memahami dan menguasai pembelajaran menulis sesuai kaidah tata bahasa Indonesia. Dari penjelasan tersebut, maka pembelajaran menulis teks eksposisi perlu ditingkatkan dan harus diberi perhatian lebih intensif agar proses pembelajaran berjalan dengan baik.

Kurangnya latihan adalah akibat dari kemalasan siswa.Rasa malas tersebut biasanya lebih disebabkan kurangnya motivasi dalam diri siswa. Mereka tidak tahu untuk apa sebenarnya mereka menulis. Untuk itu, siswa perlu diberikan motivasi agar tergugah untuk membuat tulisan. Dari hasil penelitian, diketahui bahwa pembelajaran menulis di SMA tersebut belum sepenuhnya diterapkan dengan pendekatan proses. Karena dalam menulis sebuah teks siswa masih memiliki masalah yang sangat serius termasuk dalam penguasaan kaidah bahasanya. Tidak adanya kontrol yang kuat dalam proses menulis membuat kesalahan berbahasa tersebut terjadi secara berkelanjutan.

Mayoritas siswa tersebut mengaku jarang berlatih menulis selain dalam mata pelajaran Bahasa Indonesia yang mengharuskan mereka untuk menulis.Oleh karena itu, wajar jika masih ditemukan banyak kesalahan berbahasa dalam tulisan mereka mereka yang meliputi semua komponen kebahasaan. Akan tetapi hal tersebut harus segera diatasi oleh guru yang mengajar di sekolah tersebut.Sebagai suatu keterampilan yang produktif dan ekspresif, keterampilan menulis tentu tidak mudahdikuasai oleh seseorang begitu saja.

Oleh karena itu, jika seseorang ingin dapat memiliki keterampilan menulis yang baik, maka ia harus melewati tahap-tahap atau proses menulis untuk menghasilkan tulisan yang baik dan benar. Sehingga dengan mengikuti tahapan-tahapan yang semestinya dilakukan, siswa akan belajar dan memperoleh pengalaman bagaimana proses menulis yang benar.Tentu saja adanya kesalahan-kesalahan berbahasa khususnya kesalahan struktur frasa dalam teks yang dibuat oleh siswa tersebut dapat dikurangi karena sebelum tahap akhir penulisan, siswa terlebih dahulu melakukan tahap revisi dan pengeditan. Jadi, hasil karangan final siswa 
adalah teks yang sudah mengalami tahap perbaikan sebaik-baiknya bukan berupa teks sementara lagi.

\section{PENUTUP}

Berdasarkan hasil penelitian ini dapat disimpulkan bahwa bentuk kesalahan struktur frasa teks eksposisi siswa kelas X SMA Negeri 15 Medan tahun pembelajaran 2016/2017 terbagi atas 5 macam, yaitu frasa benda, frasa kerja, frasa sifat, frasa depan dan frasa keterangan. Dari kelima bentuk kesalahan struktur frasa tersebut terdapat bentuk kesalahan yang paling menonjol dan sering dilakukan, yaitu frasa depan. Dan juga banyaknya kesalahan struktur frasa yang dibuat oleh siswa tidaklah sama. Ada kesalahan struktur frasa yang ditemukan hanya satu, dua bahkan lebih dari bentuk kesalahan struktur frasa, ada pula yang tidak ada sama sekali. Hal ini menunjukkan bahwa sistematika penulisan dan pemahaman siswa mengenai struktur frasa harus lebih ditingkatkan lagi.

\section{DAFTAR PUSTAKA}

Arifin, Zaenal dan Junaiyah Matanggui. 2014. Analisis Kesalahan Berbahasa Indonesia. Tangerang: Pustaka Mandiri.

Chaer, Abdul. 2008. Sintaksis Bahasa Indonesia. Jakarta: PT Rineka Cipta

Finoza, Lamuddin. 2009. Komposisi Bahasa Indonesi. Jakarta: Diksi.

Hastuti, Sri. 2003. Sekitar Analisis Kesalahan Berbahasa Indonesia. Yogyakarta: PT Mitra Gama.

Irwandy. 2013. Metode Penelitian. Jakarta: Halaman Moeka.

Mahsun. 2013. Teks dalam Pembelajaran Bahasa Indonesia Kurikulum 2013.Jakarta: PT Raja Grafindo Persada.

Moleong.Lexy J. 2010.Metodologi Penelitian Kualitatif. Bandung: PT Remaja Rosdakarya

Tarigan, H. G. 2005. Menulis sebagai Suatu Keterampilan Berbahasa. Bandung: Angkasa 